\title{
Uji Aktivitas Antibakteri Ekstrak Etanol Daun Pare (Momordica charantia L.) Terhadap Bakteri Staphylococcus aureus ATCC 25923
}

\author{
Kholila Rizqiana1, Dwi Bagus Pambudi ${ }^{2 *}$, St. Rahmatullah ${ }^{3}$, Urmatul Waznah4 \\ 1,2,3,4 Program Studi Sarjana Farmasi, Universitas Muhammadiyah Pekajangan Pekalongan, \\ Indonesia \\ *email: dwibagus589@gmail.com*
}

\begin{abstract}
Bitter gourd as a traditional medicine has a chemical content in its leaves that are useful as antimicrobials and as antioxidants. According to research by Tessa Undap, 2017 shows that bitter melon leaves have an inhibitory power against the growth of Staphylococcus aureus bacteria by inhibiting protein synthesis. The purpose of this study was to determine the antibacterial activity of bitter melon leaf extract (Momordica charantia L.). The research method used in this study is the disc diffusion method. Data was collected by measuring the diameter of the clear zone formed in each treatment. The antibacterial results showed that the $9 \%$ extract concentration had the highest inhibitory power.
\end{abstract}

Keywords: Antibacterial, Pare Leaf Extract, Granules, Staphylococcus aureus.

\begin{abstract}
Abstrak
Tanaman pare sebagai obat tradisional memiliki kandungan kimia dalam daunnya yang bermanfaat sebagai antimikroba dan sebagai antioksidan. Menurut penelitian oleh Tessa Undap, 2017 menunjukkan bahwa daun pare mempunyai daya hambat terhadap pertumbuhan bakteri Staphylococcus aureus dengan cara menghambat sintesis protein. Adanya kandungan flavonoid dalam daun pare dapat menghambat pertumbuhan bakteri Staphylococcus aureus yang dapat mengkoagulasi protein pada sel bakteri. Tujuan dari penelitian ini yaitu untuk mengetahui aktivitas antibakteri yang terkandung dalam ekstrak daun pare (Momordica charantia L.). Metode penelitian yang digunakan dalam penelitian ini yaitu metode difusi cakram disk. Pengumpulan data dilakukan dengan cara mengukur diameter zona bening yang terbentuk pada setiap perlakuan. Hasil antibakteri yaitu menunjukkan bahwa konsentrasi ekstrak $9 \%$ mempunyai daya hambat paling tinggi.
\end{abstract}

Kata kunci: Antibakteri, Ekstrak Daun Pare, Granul, Staphylococcus aureus.

\section{Pendahuluan}

Tanaman pare adalah tanaman yang berasal dari benua Asia, tanaman pare termasuk dalam familia Cucurbitaceae. Pare adalah tanaman semak semusim yang dapat tumbuh pada dataran rendah serta dapat ditemukan tumbuh liar di tanah ataupun dapat ditanam di pekarangan. Tanaman pare ini dapat tumbuh dengan cara merambat, sulur yang berbentuk spiral, daunnya berbentuk tunggal, berbulu, berbentuk lekuk, dan bertangkai sepanjang $\pm 10 \mathrm{~cm}$ dan bunganya berwarna kuning muda (Leelaprakash, 2011).

Selain buahnya yang memiliki kandungan momordicin dan charantin, belum banyak orang yang mengetahui manfaat lain dari daun pare yang memiliki kandungan kimia seperti tannin, flavonoid, saponin, triterpenoid, glikosida dan alkaloid. Kandungan kimia dalam daun pare tersebut dapat bermanfaat sebagai antimikroba dan sebagai antioksidan (Leelaprakash, 2011). Senyawa saponin, flavonoid, dan alkaloid dapat 


\section{Prosiding Seminar Nasional Kesehatan Lembaga Penelitian dan Pengabdian Masyarakat Universitas Muhammadiyah Pekajangan Pekalongan}

bekerja sebagai antimikroba. Diabsopsinya saponin pada permukaan sel akan menyebabkan kerusakan sel dengan naiknya permeabilitas, sehingga bahan esensial yang dibutuhkan oleh bakteri untuk kehidupannya hilang dan dapat menyebakan kematian sel bakteri.

Bakteri merupakan makluk hidup mikroskopis bersel tunggal (uniseluler), bakteri merupakan organisme yang memiliki dinding sel. Beberapa bakteri dapat memiliki keuntunga dan ada juga bakteri yang dapat merugikan bagi orang lain (Didimus Tanah Boleng, 2015 ). Antimikroba adalah senyawa yang dapat memberantas infeksi pada manusia, zat antimikroba ada yang bersifat bakteriostatik dan bakterisida. Salah satu zat bakteriostatik yang biasa digunakan yaitu kloramfenikol, eritromisin dan novobiosin (Sunaryo, 2014).

Sterilisasi merupakan cara atau proses yang dilakukan untuk mematikan dan menghilangkan semua organisme yang berada pada suatu benda pemindahan biakan bakteri secara aseptik menggunakan salah satu cara sterilisasi yaitu dengan pembakaran (Cahyani, 2014).

\section{Metode}

\section{Bahan}

Bahan yang digunakan dalam penelitian ini adalah ekstrak daun pare, etanol $96 \%$, Medium Mueller Hinton Agar (MHA), bakteri Staphylococcus aureus.

\section{Alat}

Peralatan yang digunakan dalam penelitian ini adalah blender (Philipsß), tabung reaksi (Pyrex(B)), lumpang dan alu, ayakan mesh nomor 40, kertas timbang, timbangan analitik (Chyoß), pipet tetes, pH meter (Jenway(B), jarum ose, jangka sorong, waterbath, rotary vacum evaporator (Buci-R210ß), hot plate (MS-H280PRO®), inkubator (Memmert(B), autoklaf (Presto(B), laminator air flow (Chuaire(B)).

\section{Prosedur_Kerja}

\section{Pembuatan Simplisia}

Sampel daun pare (Momordica charantia L.) dipetik dan dilakukan sortasi basah dan dicuci bersih. Sampel kemudian dirajang dan dikeringkan cara diangin-anginkan di bawah sinar matahari dengan ditutup menggunakan kain hitam sampai kering. Simplisia yang sudah kering dibuat dalam bentuk serbuk dengan cara diblender dan diayak dengan pengayak mesh 40 menjadi serbuk dengan ukuran homogeny. Disimpan pada wadah yang kering tertutup rapat dalam ruangan yang terlindung dari cahaya matahari.

\section{Pembuatan Ekstrak}

Simpilisia yang telah dikeringkan dan dihaluskan kemudian ditimbang sebanyak $1000 \mathrm{~g}$ dan dimasukkan ke dalam toples besar dan direndam dengan 5 liter etanol $96 \%$, rendaman tersebut sambil sekali-kali diaduk. Ekstrak disaring dengan menggunakan kertas whatman atau dengan kain flanel. Ampas yang diperoleh kemudian dimaserasi lagi dengan jumlah pelarut sebanyak 3 liter sampai hasil filtrat maserasi mendekati warna pelarut etanol 96\% (tersari sempurna). Filtrat kemudian diuapkan dengan menggunakan alat rotary evaporator hingga didapatkan ekstrak kental. 


\section{Prosiding Seminar Nasional Kesehatan $\mid 2021$ \\ Lembaga Penelitian dan Pengabdian Masyarakat Universitas Muhammadiyah Pekajangan Pekalongan}

\section{Skrining Fitokimia}

Ekstrak kental yang telah dihasilkan kemudian dilakukan skrining fitokimia untuk mengidentifikasi adanya senyawa aktif yang terkandung dalam ekstrak daun pare.

a. Uji identifikasi alkaloid

Satu $\mathrm{mL}$ ekstrak dimasukkan ke dalam tabung reaksi dan ditambahkan dengan 3 tetes pereaksi dragendorff. Hasil uji yang terdapat endapan berwarna jingga atau merah bata, maka ekstrak positif mengandung alkaloid (Andi Nafisah Tendri Adjeng, 2019).

b. Uji identifikasi flavonoid

Sebanyak $200 \mathrm{mg}$ ekstrak ditambahakan $5 \mathrm{~mL}$ etanol kemudian dipanaskan selama 5 menit dan disaring. Selanjutnya filtrat ditambahkan $5 \mathrm{~mL} \mathrm{HCl}$ pekat dan serbuk Mg kocok sampai homogen. Hasil positif menunjukkan perubahan warna menjadi warna merah, kuning atau jingga (Sastrawan I. S., 2013).

c. Uji identifikasi saponin

Satu $\mathrm{mL}$ ekstrak dimasukkan ke dalam tabung reaksi dan ditambahkan dengan $1 \mathrm{ml}$ aquadest hangat kemudian digojog kuat selama \pm 1 menit. Jika terbentuk buih yang stabil, maka ekstrak positif mengandung saponin (Andi Nafisah Tendri Adjeng, 2019).

d. Uji identifikasi tanin

Satu $\mathrm{mL}$ ekstrak dimasukkan ke dalam tabung reaksi dan ditambahkan dengan $1 \mathrm{ml} \mathrm{FeCl} 31 \%$. Jika terbentuk larutan berwarna hijau hingga biru kehitaman, maka ekstrak positif mengandung tanin. (Andi Nafisah Tendri Adjeng, 2019).

e. Uji identifikasi fenol

Satu $\mathrm{mL}$ ekstrak yang akan diuji ditambahkan dengan 3-4 tetes larutan besi (III) klorida. Hasil positif pada uji fenol ditunjukkan dengan terjadinya perubahan warna hitam kebiruan menunjukkan adanya fenol (Hanani, 2015).

f. Uji identifikasi steroid dan terpenoid

Satu $\mathrm{mL}$ ekstrak ditambah 2 tetes asam asetat anhidrat dan 1 tetes $\mathrm{H}_{2} \mathrm{SO}_{4}$. Hasil positif pada pengujian steroid ditunjukkan dengan adanya perubahan warna menjadi hiaju kehitaman dan pada terpenoid terbentuk berwarna biru kehijauan menunjukkan adanya terpenoid (Hanani, 2015).

\section{Uji Aktivitas Antibakteri Ekstrak Daun Pare}

a. Sterilisasi alat

Sterilisasi alat dilakukan untuk semua peralatan yang akan digunakan, yaitu dengan cara semua alat dibungkus menggunakan kertas dan disterilkan dalam autoklaf pada suhu $121^{\circ} \mathrm{C}$ dengan tekanan $2 \mathrm{~atm}$ selam 15 menit (Muhibah, 2013). 


\section{Prosiding Seminar Nasional Kesehatan \\ Lembaga Penelitian dan Pengabdian Masyarakat Universitas Muhammadiyah Pekajangan Pekalongan}

\section{b. Pembuatan media}

Sebanyak 11,4 gr MHA (Mueller-Hinton Agar) ditimbang dan dilarutkan dalam $300 \mathrm{~mL}$ aquadest menggunakan erlenmeyer $500 \mathrm{~mL}$. Media yang telah ditimbang dan dilarutkan dipanaskan sampai mendidih di atas hotplate, diatur $\mathrm{pH}$ media hingga sampai 7,4 dan disterilisasi dengan autoklaf pada suhu $121^{\circ} \mathrm{C}$ tekanan 2 atm selama 15 menit. Media MHA digunakan sebagai media tanam bakteri Staphylococcus aureus, tuangkan media dalam cawan petri sebanyak 30 $\mathrm{mL}$, biarkan sampai memadat (Reanza Musmulya Putri, 2019).

c. Pembuatan suspensi bakteri

Bakteri uji yang telah diinokulasi diambil sebanyak 2 ose steril lalu disuspensikan ke dalam tabung yang berisi $10 \mathrm{~mL}$ larutan $\mathrm{NaCl}$ 0,9\%. Selanjutnya permbuatan larutan standar kekeruhan (larutan Mc. Farland) menggunakan $\mathrm{H}_{2} \mathrm{SO}_{4}$ 0,36N sebanyak 99,5 mL dicampurkan dengan larutan $\mathrm{BaCl}_{2} 2 \mathrm{H}_{2} \mathrm{O} 1,175 \%$ sebanyak $0,5 \mathrm{~mL}$ dalam Erlenmeyer. Kemudian dikocok sampai terbentuk larutan yang keruh. Kekeruhan ini dipakai sebagai standar kekeruhan suspensi bakteri bakteri uji (Meria Afnizar, 2016).

d. Kontrol positif dan Kontrol negatif

Kontrol positif yang digunakan adalah cakram antibiotik kloramfenikol $30 \mu \mathrm{g}$ dan kontrol negatif yang digunakan adalah pelarut DMSO (Tuntun, 2016).

e. Prosedur uji antibakteri ekstrak daun pare Metode Difusi dengan menggunakan cakram disk

Pengujian aktivitas antibakteri pada ekstrak dilakukan dengan menggunakan cakram disk yang masing-masing berukuran $6 \mathrm{~mm}$. Suspensi bakteri diinokulasikan ke dalam media MHA padat dengan metode spread plate. Sebanyak $1 \mathrm{~mL}$ suspensi bakteri dituangkan ke dalam cawan petri berisi media MHA dan diratakan.

Kertas cakram diambil secara aseptis menggunakan pinset yang telah disterilisasi. Kertas cakram tersebut dicelupkan pada masing-masing konsentrasi ekstrak selama 1 jam, kemudian diletakkan diatas media yang berisi bakteri uji. Kemudian diinkubasi selama $1 \times 24$ jam pada suhu $37^{\circ} \mathrm{C}$. Efektivitas ekstrak dapat dilihat dari zona hambat yang didapatkan. Zona hambat terlihat lebih bening daripada daerah sekitarnya dan tidak ditumbuhi bakteri. Zona hambat yang terbentuk diukur dengan menggunakan jangka sorong (Kristanti M. , 2014).

\section{Hasil dan Pembahasan}

\section{Hasil}

Tabel 3.1 Rendemen dan kadar air Ekstrak Daun Pare

\begin{tabular}{cc}
\hline Karakteristik & Ekstrak Daun Pare \\
\hline Bobot simplisia (gram) & 1.000 \\
\hline Bobot ekstrak (gram) & 161,9 \\
\hline Rendemen (\%) & 16,19 \\
\hline Kadar air (\%) & 1,23 \\
\hline
\end{tabular}




\section{Prosiding Seminar Nasional Kesehatan $\mid 2021$ Lembaga Penelitian dan Pengabdian Masyarakat Universitas Muhammadiyah Pekajangan Pekalongan}

Tabel 3.2 Hasil Skrining Fitokimia

\begin{tabular}{ccc}
\hline Senyawa aktif & Perubahan & Kesimpulan \\
\hline Alkaloid & $\begin{array}{c}\text { Terbentuk endapan } \\
\text { merah bata }\end{array}$ & + \\
\hline Flavonoid & warna merah & + \\
\hline Fenol & Coklat kekuningan & - \\
\hline Saponin & Terbentuk buih & + \\
\hline Steroid & Hijau kehitaman & + \\
\hline Triterpenoid & Biru kehijauan & + \\
\hline Tanin & Biru kehitaman & + \\
\hline
\end{tabular}

Tabel 3.3 Uji Aktivitas Antibakteri Ekstrak Daun Pare

\begin{tabular}{cc}
\hline Konsentrasi Ekstrak & Daya Hambat Bakteri \\
\hline $5 \%$ & $4,9 \mathrm{~mm}$ \\
\hline $7 \%$ & $5,7 \mathrm{~mm}$ \\
\hline $9 \%$ & $7,9 \mathrm{~mm}$ \\
\hline Kontrol positif & $12,6 \mathrm{~mm}$ \\
\hline Kontrol negatif & $0 \mathrm{~mm}$ \\
\hline
\end{tabular}

\section{Pembahasan}

Pembuatan serbuk simplisia ekstrak daun pare dilakukan dilakukan dengan cara mengambil sampel daun pare yang kemudian dilakukan sortasi basah untuk menghilangkan kotoran-kotoran yang menempel pada daun. Setelah proses sortasi basah, sampel kemudian dicuci dengan menggunakan air bersih yang mengalir hingga kotoran yang menempel pada daun hilang. Daun yang telah dicuci lalu dilakukan proses perajangan untuk mempercepat proses pengeringan. Pengeringan dilakukan dengan cara diangin-anginkan di bawah sinar matahari dengan ditutupi kain hitam. Setelah proses pengeringan, daun yang telah kering dihaluskan dengan menggunakan blender. Serbuk simplisia yang telah dihaluskan kemudian di ayak dengan menggunakan ayakan mesh 40.

Proses pembuatan ekstrak daun pare dilakukan dengan metode maserasi dengan menggunakan pelarut etanol 96\%. Sebanyak $1 \mathrm{~kg}$ serbuk simplisia di maserasi dengan menggunakan 5 liter etanol selama $5 \times 24$ jam dengan dilakukan pengadukkan selama 1 jam. Setelah proses maserasi, larutan di saring menggunakan kain flanel untuk mendapatkan filtratnya. Ampas yang tersisa dari hasil maserasi dilakukan remaserasi dengan pelarut yang selama selama $3 \times 24$ jam. Filtrat yang dihasilkan dari proses maserasi dan remaserasi kemudian di diuapkan dengan menggunakan rotary evaporator hingga didapatkan ekstrak yang kental.

Hasil penelitian yang telah menunjukkan bahwa ekstrak etanol daun pare mengandung senyawa alkaloid, flavonoid, saponin, steroid, triterpenoid dan tanin. Hasil kadar air yang diperoleh dari ektrak daun pare yaitu sebesar 1,23\%. Hasil tersebut memenuhi persyaratan mutu $<10 \%$. Nilai kadar air yang terlalu tinggi atau (> 10\%) akan menyebabkan tumbuhnya mikroba yang dapat mengakibatkan terjadinya penurunan stabilitas ekstrak (Saifudin, 2011). 


\section{Prosiding Seminar Nasional Kesehatan Lembaga Penelitian dan Pengabdian Masyarakat Universitas Muhammadiyah Pekajangan Pekalongan}

Dari hasil uji aktivitas antibakeri diperoleh data bahwa dengan konsentrasi ekstrak 5\%, 7\% dan 9\% dapat menghambat pertumbuhan bakteri Staphylococcus aureus. Daya hambat yang dihasilkan dari masing-masing konsentrasi yaitu konsentrasi $5 \%$ sebesar 4,9 mm, konsentrasi 7\% sebesar 5,7 mm dan konsentrasi $9 \%$ sebesar 7,9 $\mathrm{mm}$. Daya hambat yang diperoleh dari uji tersebut termasuk dalam kategori sedang dalam persyaratan zona hambat bakteri. Sedangkan pada kontrol positif diperoleh zona hambat sebesar $12,6 \mathrm{~mm}$ dan kontrol negatif pada pengujian yang digunakan tidak menghasilkan daya hambat antibakteri karena tidak menunjukkan adanya zona bening di sekitar cakram.

\section{Kesimpulan}

Berdasarkan hasil penelitian yang telah dilakukan, dapat disimpulkan bahwa ekstrak etanol daun pare mempunyai senyawa yang dapat menghambat aktivitas antibakteri. Dari hasil penelitian yang dilakukan diperoleh konsentrasi 5\%, 7\% dan 9\% yang dapat menghambat bakteri Staphylococcus aureus. Semakin tinggi konsentrasi ekstrak yang digunakan maka semakin besar daya hambat antibakterinya

\section{Referensi}

[1] Andi Nafisah Tendri Adjeng, S. H. (2019). Skrining Fitokimia dan Evaluasi Sediaan Sabun Cair Ekstrak Etanol 96\% Kulit Buah Salak Pondoh (Salacca zalacca (Gaertn.) Voss.) sebagai Antioksidan. Jurnal Farmasi, Sains dan Kesehatan.

[2] Didimus Tanah Boleng, M. (2015 ). Konsep-Konsep Dasar Bakteriologi . Malang: Universitas Muhammadiyah Malang Press.

[3] Cahyani, V. (2014). Petunjuk Praktikum Mikrobiologi Pangan. Surakarta: Universitas Sebelas Maret.

[4] Hanani, E. (2015). Analisis fitokimia. Jakarta: Buku Kedokteran EGC.

[5] Kristanti, M. (2014). Uji Aktivitas Antibakteri dari Ekstrak Tanaman Suruhan (Peperomia pellucida L.) Terhadap Pertymbuhan Eschericia coli dan Bacillus cereus Secara In-Vitro serta Kaitannya dengan Pembelajaran Biologi SMA kelas X,. Skripsi, Universitas Sanata Dharma.

[6] Leelaprakash, G. R. (2011). In Vitro Antimicrobial and Antioxidant Activity of Momordica charantia Leave. Pharmacophore. 2(4), 207-215.

[7] Meria Afnizar, N. M. (2016). Uji Aktivitas Antibakteri Ekstrak Daun Mahkota Dewa (Phaleria macrocarpa) Terhadap Bakteri Staphylococcusaureus.

[8] Muhibah, S. R. (2013). Uji Golongan Senyawa Aktif dan Uji Aktivitas Antibakteri Ekstrak Alga Merah Eucheuma Cottoni dari Petani Lobuk Madura. . Skripsi Tidak Diterbitkan. Malang: Jurusan Kimia Universitas Islam Negeri (UIN) Maulana Malik Ibrahim Malang.

[9] Mukti, D. (2012). Uji Efektivitas Antibakteri Ekstrak Etanol Buah Pare (Momordica charantia L.) terhadap Streptococcus mutans penyebab Karies Gigi. Universitas Pakuan Bogor. 


\section{Prosiding Seminar Nasional Kesehatan Lembaga Penelitian dan Pengabdian Masyarakat Universitas Muhammadiyah Pekajangan Pekalongan}

[10] Reanza Musmulya Putri, V. E. (2019). Perbandingan Uji Aktivitas Antibakteri dari Ekstrak Etanol Bunga, Daun dan Akar Tumbuhan Rosella (Hibiscus sabdariffa L.) Terhadap Bakteri Staphylococcus aureus.

[11] Saifudin, A. R. (2011). Standarisasi Bahan Obat Alam. Yogyakarta: Graha Ilmu.

[12] Sastrawan, I. S. (2013). Skrining Fitokimia dan Uji Aktivitas Antioksidan Ekstrak Biji Ada ( Feniculum vulgare) Menggunakan Metode DPPH . Jurnal Ilmiah Sains, 2, $p 13$.

[13] Sunaryo. (2014). Psikologi untuk Keperawatan. Jakarta: Buku Kedokteran edisi kedua. EGC.

[14] Tessa Undap, S. S. (2017). Potensi Antibakteri Ekstrak Etanol Daun Pare. Biologi FMIPA Universitas Negeri Manado, vol 5 no 2.

[15] Tuntun, M. (2016). Uji Efektivitas Ekstrak Daun Pepaya (Carica papaya L.) Terhadap Pertumbuhan Bakteri Eschericia coli dan Staphylococcus aureus. 